\title{
8. Sınıf T.C. İnkılap Tarihi ve Atatürkçülük Dersinde Artırılmış Gerçeklik Uygulamalarının Öğrencilerin Akademik Başarılarına Etkisi ve Öğrencilerin Artırılmış Gerçeklik Uygulamasına Karşı Tutumları
}

\author{
Cansu Alınlıa \\ Fatih Yazıcl b \\ a Yüksek Lisans Öğrencisi, ORCID: 0000-0003-2496-7761 \\ b Doç.Dr., Tokat Gaziosmanpaşa Üniversitesi, ORCID: 0000-0003-2121-8538
}

\begin{tabular}{|c|c|}
\hline ÖZET & MAKALE BİLGİSİ \\
\hline $\begin{array}{l}\text { Bu çalışmanın amacı, 8.sını T.C. İnkılap Tarihi ve Atatürkçülük dersinde } \\
\text { artırılmış gerçeklik uygulaması ile konuların öğretiminin, öğrencilerin } \\
\text { akademik başarılarına etkisini ve ögrencilerin artırılmış gerçeklik } \\
\text { uygulamasına karşı tutumlarını ortaya koymaktır. Çalışma 2019-2020 eğitim } \\
\text { öğretim yılında Tokat il merkezinde bulunan bir ortaokulda } 59 \text { öğrenci ile } \\
\text { gerçekleştirilmiştir. Araştırmada karma desen kullanılmıştır. Nicel boyutta } \\
\text { öntest-sontest kontrol gruplu yarı deneysel yöntem; nitel boyutunda ise } \\
\text { olgubilim yönteminden yararlanılmıştır. Veriler başarı testi, Küçük, Yılmaz, } \\
\text { Baydaş ve Göktaş (2014) tarafından geliştirilen Artırılmış Gerçeklik Tutum } \\
\text { Ölçeği ve açık uçlu soru formu olmak üzere üç farklı veri toplama aracı ile } \\
\text { elde edilmiştir. Nicel verilerin analizinde Mann-Whitney U, Wilcoxon ve } \\
\text { betimsel istatistikler; nitel verilerde ise içerik analizi yöntemi kullanılmıştır. } \\
\text { Elde edilen bulgulara göre öğrencilerin artırılmış gerçeklik uygulaması ile } \\
\text { işlenen derslerde, geleneksel yöntemle işlenen derse göre daha başarılı } \\
\text { oldukları, daha çok verim aldıkları, derslere karşı daha ilgi ve istekle } \\
\text { girdikleri, akılda kalıcı görseller sayesinde konunun somutlaştırıldığı ve } \\
\text { öğrenmeyi içselleştirdikleri sonuçlarına ulaşılmış̧ı̈ı̈. Bununla birlikte deney } \\
\text { grubu öğrencilerinin uygulamaya karşı olumlu yönde tutuma sahip olduğu } \\
\text { görülmüștür. }\end{array}$ & $\begin{array}{l}\text { Anahtar Kelimeler } \\
\text { Artırılmış Gerçeklik, } \\
\text { 8. Sınıf T.C. İnkılap } \\
\text { Tarihi ve } \\
\text { Atatürkçülük Dersi, } \\
\text { Başarı, Tutum }\end{array}$ \\
\hline
\end{tabular}

Atıf Bilgisi: Alınlı, C. ve Yazıcı, F. (2020). 8. Sınıf T.C. İnkılap Tarihi ve Atatürkçülük dersinde artırılmış gerçeklik uygulamalarının öğrencilerin akademik başarılarına etkisi ve öğrencilerin artırılmış gerçeklik uygulamasına karşı tutumları. Uluslararası Türk Eğitim Bilimleri Dergisi, 8 (15), 99-113.

Sorumlu yazar: Cansu Alınlı, e-posta: cansualinli@gmail.com 


\title{
The Effect of Augmented Reality Practices on Students' Academic Achievement in Grade 8th T.R. the History of Revolution and Kemalism Course and Attitudes of Students towards Augmented Reality Practice
}

\author{
Cansu Alınl ${ }^{\mathrm{a}}$ \\ Fatih Yazıcl ${ }^{b}$ \\ a Graduate Student, ORCID: 0000-0003-2496-7761 \\ b Assoc.Prof.Dr., Tokat Gaziosmanpaşa University, ORCID: 0000-0003-2121-8538
}

ABSTRACT
The purpose of this study was to determine the effects of the teaching of the
subjects through augmented reality on the academic achievement of the Article Type
students and to reveal their attitudes towards the augmented reality practice Research
in the 8th grade Turkish Revolution History and Kemalism course. The study
was carried out with 59 students in a secondary school in the city center of Article Background
Tokat in the $2019-2020$ academic year. The Mixed method was used in the Received:
research. Pretest-posttest control group semi-experimental design was used 15.08 .2020
in the quantitative phase while phenomenology was employed in the Accepted:
qualitative phase. The data were gathered using achievement test, 30.09.2020
Augmented Reality Attitude Scale developed by Küçuk, Yllmaz, Baydaş and
Göktaş (2014) and an open-ended questionnaire. Mann-Whitney U, Key Words
Wilcoxon and descriptive statistics were performed to analyze the Augmented Reality,
quantitative data while content analysis was performed to analyze the 8. Grade T.R. History
qualitative data. According to the findings, it was concluded that the of Revelation and
students were more successful, more efficient, more interested and Kemalism Course,
enthusiast, and the subject was concretized and learning was internalized Achivement,
thanks to the memorable visuals in lessons conducted through augmented Attitude
reality compared to traditional lessons. Moreover, it was observed that the
experimental group students had positive attitudes towards the
implementation.

To cite this article: Alınl, C. \& Yazıc1, F. (2020). The effect of augmented reality practices on students' academic achievement in grade 8th T.R. the History of Revolution and Kemalism Course and attitudes of students towards augmented reality practice. International Journal of Turkish Educational Sciences, 8 (15), 99-113.

Corresponding Author: Cansu Alınlı, e-mail: cansualinli@gmail.com 
8. Sınıf T.C. İnkılap Tarihi ve Atatürkçülük Dersinde Artırılmış Gerçeklik Uygulamalarının Öğrencilerin Akademik Başarılarına Etkisi ve Öğrencilerin Artırılmış Gerçeklik Uygulamasına Karşı Tutumları

\section{Giriş}

Bilim ve teknolojide yaşanan değişim ve gelişim toplumsal yaşamın hemen her alanında olduğu gibi eğitim kurumlarında da etkili olmuştur. Eğitimin önemli amaçlarından biri de toplumun ihtiyaçlarına yönelik bireyler yetiştirmek olduğuna göre günümüz çağının gerektirdiği perspektifle eğitim-öğretim hayatında teknolojiden yararlanmak gerekmektedir (Aydın, 2003). Nitekim 21. yüzyılın becerileri artık okulda ve işte başarılı olmak için gerekli olan dijital becerileri ifade etmektedir (Jenkins, Purushotma, Weigel, Clinton ve Robison, 2009). Teknoloji kullanımı, öğrencilerin sosyal çalışmalara ilgilerini artırması, yaratıcılıklarını ve üst düzey düşünme becerilerini geliştirmeleri amacıyla öğrenci merkezli öğrenme etkinliklerini yürütmelerini sağlamaktadır (Zhao, 2007). Aynı zamanda öğrencilerin eleştirel düşünme becerilerini geliştirmekte ve akademik başarılarında da katkı sağlamaktadır. Sosyal bilgiler eğitiminde de öğrencilerin bilgilerinin inşasına izin vererek, öğrenmenin anlamlı bağlamlarda gerçekleşmesini sağlayarak ve öğrenmeyi öğrencilerin kendi deneyimleriyle ilişkilendirerek onların iyi birer vatandaş olabilmeleri için gerekli bilgi, beceri ve değerlerle hazırlamaktadır (Heafner,2004; Rice ve Wilson, 1999). Günümüz vatandaşlık becerileri de bilgiye erişebilmeyi, bilgiyi belli hedefler doğrultusunda kullanabilmeyi ve analiz etmeyi kapsamaktadır. Teknoloji aracılığıyla da bunlara doğrudan ulaşabilmektedir (Braun, 1999). Bu noktada sosyal bilgiler dersi öğretim programı (MEB, 2018) ve T.C. İnkılap Tarihi ve Atatürkçülük dersi öğretim programı (MEB, 2018) amaçlarına baktığımızda diğer bütün eğitsel kaynaklar gibi eğitim teknolojilerinin de kullanılmasını desteklemektedir.

Günümüz eğitim ortamlarında etkileşimin sağlandığı birçok teknolojik destekli uygulama vardır. Bu uygulamalardan biri de artırılmış gerçeklik teknolojileridir. Azuma'ya (1997) göre artırılmış gerçeklik, sanal nesneler ile gerçek nesnelerin eş zamanlı olarak aynı ortamda etkileşime girmesiyle elde edilen bir teknolojidir. Benzer bir tanımlamaya göre artırılmış gerçeklik bireyin, gerçek dünya deneyimini arttırmak amacıyla dijital ve fiziksel bilgi türlerini birleştiren üç boyutlu uygulamalardır (Aoyama ve Tse, 2017; Challenor ve Ma, 2019; Özarslan, 2011; Wu, Lee, Chang ve Liang, 2013). Böylelikle deneyimsel birtakım amaçlar doğrultusunda, sanal dünya ile gerçek dünyanın bir araya gelerek bir bütün oluşturması hedeflenir (Erbaş ve Demirer, 2014).

Son on yılda, telefonlar, tabletler ve el oyun konsolları gibi akıllı cihazların yaygınlığı ve bilgi işlem gücündeki son gelişmeler sayesinde artırılmış gerçeklik günlük yaşamımızda gittikçe yaygınlaşmaktadır (Schiavi, Gechter, Gechter ve Rizzo, 2018). Artırılmış gerçeklik uygulamalarını kullanmak için artık özel donanımlara ihtiyaç duyulmamakta, bunun yerine kullanıcılar sistemi kendi cihazlarından çalıştırabilmektedir. Donanım zorlukları aşıldıkça artırılmış gerçeklik, farklı uygulama alanlarına sahip olmuştur (Challenor ve Ma, 2019). Pratikteki bu kolaylık birçok alanda olduğu gibi eğitimde de önemli bir potansiyeli ifade etmektedir (Schiavi, Gechter, Gechter ve Rizzo, 2018).

Yakın zamanda gerçekleştirilen birçok deneysel çalışmada da görüldüğü üzere öğrenme ortamlarında artırılmış gerçeklik uygulamalarının kullanılmasının, öğrenme çıtıları anlamında önemli birtakım avantajları vardır. Öncelikle belirtmek gerekir ki eğitimlerinin bir parçası olarak artırılmış gerçeklik uygulaması kullanan öğrencilerin akademik başarıları ve 
öğrenme süreklilikleri artmaktadır (Billinghurst ve Duenser, 2012). Uygun pedagojik ilkelerle kullanıldığı takdirde artırılmış gerçekliğin, öğrenilen bilgileri uzun süreli belleğe yerleştirme ve böylelikle kalıcılığını sağlama potansiyeli de bulunmaktadır (Santos, Chen, Taketomi, Yamamoto, Miyazaki ve Kato, 2013).

Akademik başarı üzerindeki olumlu etkilerinin yanı sıra artırılmış gerçeklik, görselleştirme, işbirlikli öğrenmeyi sağlama, formal ve informal öğrenme arasında köprü kurma yönleriyle de dikkat çekmektedir ( $\mathrm{Wu}$, Lee, Chang ve Liang, 2013). Böylelikle geleneksel pasif öğrenme yerine aktif öğrenme için de güçlü bir araç olarak karşımıza çıkmaktadır (Challenor ve Ma, 2019). Bu avantajlarıyla birlikte artırılmış gerçekliğin uygulandığı sınıflarda öğrenciler, öğrenme ve ilerleme hılarını kendileri kontrol edebilmekte bu da öğrenme özerkliğini sağlamaktadır (Wojciechowski ve Cellary, 2013). Öğretmen ise bir sınıfın hangi sürede daha iyi öğrenebildiği konusunda varsayımlarda bulunmak zorunda kalmamaktadır (Challenor ve Ma, 2019).

Soyut kavramların öğretilmesinde yaşanan birtakım problemlerin giderilmesi düşüncesi ile öğrenme ortamlarında yararlanılan artırılmış gerçeklik uygulamaları öğrenme-öğretme sürecinde soyut kavramların görselleştirilerek ve aynı zamanda deneyimlenerek süreç içerisinde daha iyi anlaşılmasına yardımcı olmaktadır (Abdüsselam ve Karal, 2012; Koçoğlu, Akkuş ve Özhan, 2016). Bununla birlikte öğrencilerin öğrenme sürecinde dikkatlerinin çekmesine ve süreçten zevk almasına, eleştirel düşünme ve problem çözme becerilerinin geliştirmesine etki etmektedir. Fiziksel dünyada anlatılması karmaşık olabilecek konuların öğretilmesine, bireysel öğrenmeyi desteklemesine, öğrenci-öğrenci ya da öğrenci-öğretmen arasında iş birliği sağlamasına ve iletişim becerisini güçlendirmesine de yardımcı olmaktadır.

Sözel ve soyut içeriğe sahip olan T.C. İnkılap Tarihi ve Atatürkçülük dersi, materyal olarak genellikle ders kitabının kullanılması dersin öğretiminin, düz anlatım ya da soru-cevap yöntemleriyle sınırlı kalmasına neden olmaktadır. Bu durum ise öğrencilerin derse karşı motivasyon ve hazırbulunuşluk düzeyini olumsuz yönde etkilemektedir (Tangülü, Tosun ve Kocabıyık, 2014). Çoğu öğrenci T.C. İnkılap Tarihi ve Atatürkçülük dersinde geçen soyut kavramları tam anlamıyla kavrayamamakta ya da kavram yanılgıları yaşamaktadır (Aycan, 2010). Öğrenmeyi somutlaştırması, bilgilerin kalıcılığını artırması, dersi tekdüzelikten kurtarması, öğrenmeyi zevkli hale getirmesi ve böylelikle kavram yanılgılarının da önüne geçmesi noktasında artırılmış gerçeklik, T.C. İnkılap Tarihi ve Atatürkçülük dersi öğretiminde yaşanan birçok sorunu azaltma potansiyeli taşımaktadır. Ayrıca duygusal anlayış ve empati gibi, tarih eğitimi açısından son derece önemli beceriler üzerindeki olumlu etkisi (Chang, Hou, Pan, Sung ve Chang, 2015) artırılmış gerçeklik uygulamalarını tarih dersleri için çok daha önemli kılmaktadır.

Alan yazına baktığımızda artırılmış gerçekliğin öğrenme ortamlarında kullanımı ile ilgili ülkemizde ve dünyada birtakım çalışmalar göze çarpmaktadır. Örneğin Abdüsselam ve Karal'ın (2012) fizik dersinde yapmış oldukları deneysel çalışmada, artırılmış gerçeklik uygulaması gerçekleştirilen deney grubunda akademik başarıların arttığı saptanmıştır. Çetinkaya ve Akçay'ın (2013) yapmış oldukları eğitim ortamlarında artırılmış gerçeklik uygulamalarına dikkat çektikleri çalışmalarında artırılmış gerçeklik uygulamasının öğrenmeye olumlu etkisinin olduğu sonucuna ulaşılmıştır. Di Serio, Ibanez ve Kloos'un (2013) 
8. Sınıf T.C. İnkılap Tarihi ve Atatürkçülük Dersinde Artırılmış Gerçeklik Uygulamalarının Öğrencilerin Akademik Başarılarına Etkisi ve Öğrencilerin Artırılmış Gerçeklik Uygulamasına Karşı Tutumları

yapmış oldukları çalışmada ise artırılmış gerçekliğin öğrencilerin motivasyonuna olumlu etkisinin olduğu görülmüştür.

Bilindiği kadarıyla 5. sınıf sosyal bilgiler dersi kapsamında Gümbür'ün (2019) yapmış olduğu tez çalışması dışında, alanda bu konuda yapılan bir araştırma bulunmamakla birlikte 8. sınıf T.C. İnkılap Tarihi ve Atatürkçülük dersinde artırılmış gerçeklik uygulaması ile konuların öğretimine etkisi ve öğrencilerin artırılmış gerçeklik uygulamasına karşı tutumlarının belirlenmesi amacıyla yapılmış olan bu çalışma, eğitimde kullanımı üzerine yapılmış olan diğer artırılmış gerçeklikle ilgili araştırmalara da çeşitlilik sağlayacaktır.

\section{Araştırmanın Amacı}

Bu çalışmanın amacı, 8.sınıf T.C. İnkılap Tarihi ve Atatürkçülük dersinde artırılmış gerçeklik uygulaması ile konuların öğretiminin öğrencilerin akademik başarılarına etkisini ve artırılmış gerçeklik uygulamasına karşı tutumlarını araştırmaktır. Bu amaç doğrultusunda ise şu sorulara cevap aranmıştır:

1. Artırılmış gerçeklik uygulamalarının ortaokul 8. sınıf öğrencilerinin akademik başarılarına etkisi nedir?

2. Artırılmış gerçeklik uygulamalarına yönelik öğrencilerin tutumları nasıldır?

3. Artırılmış gerçeklik uygulaması ile işlenen dersin sürecine ilişkin öğrenci görüşleri nelerdir?

4. Artırılmış gerçeklik uygulamalarının öğrencilere katkıları nelerdir?

\section{Yöntem}

\section{Araştırma Modeli}

Araştırmada 8. sınıf T.C. İnkılap Tarihi ve Atatürkçülük dersinde artırılmış gerçeklik uygulamalarının öğrencilerin akademik başarılarına etkisini ve öğrencilerin artırılmış gerçeklik uygulamasına yönelik tutumlarını incelemek için karma desen kullanılmıştır. Yıldırım ve Şimşek'e (2018) göre karma desen, araştırma problemini kapsamlı ve çok boyutlu incelemek amacıyla nicel ve nitel yöntemlerin birlikte kullanıldı̆̆ 1 araştırmalardır. Bu araştırmada nitel ve nicel verilerin ayrı ayrı analiz edildiği fakat birlikte yorumlandığ yansıyan paralel karma yöntem deseninden yararlanılmıştır.

Çalışmanın nicel boyutunda artırılmış gerçeklik uygulamalarının öğrenmeye etkisini araştırmak için öntest-sontest kontrol gruplu yarı deneysel desen kullanılmıştır. Çalışmanın nitel boyutunda ise olgubilim yöntemi kullanılmıştır. Olgubilim, bireylerin bir olguya ait yaşantılarını, algılarını ve bunlara yüklediği anlamların ortaya çıkmasını amaçlayan bir araştırma yöntemidir (Yıldırım ve Şimşek, 2018). 


\section{Evren ve Örneklem}

Araştırmanın evrenini, 2019-2020 öğretim yılında Tokat ili merkezinde öğrenim gören 8.sınıf öğrencileri oluşturmaktadır. Araştırmanın örneklemini ise Tokat ili merkezindeki bir ortaokulun 8.sınıfında öğrenim gören 59 öğrenci oluşturmaktadır. Deney grubu öğrencileri 16 'sı kız ve 15'i erkek öğrenci olmak üzere 31 kişiden oluşmaktadır. Kontrol grubu öğrencileri 15'i kız ve 13'ü erkek öğrenci olmak üzere 28 kişiden oluşmaktadır. Araştırmanın örneklemi amaçlı örneklem yöntemi olup, araştırmanın amacına bağlı olarak bilgi açısından zengin durumların seçilerek derinlemesine araştırma yapılmasına olanak sağlamaktadır (Büyüköztürk, Çakmak, Akgün, Karadeniz ve Demirel, 2019). Bu araştırmada da T.C. İnkılâp Tarihi ve Atatürkçülük dersini gördükleri için 8. Sınıf öğrencilerinden yararlanılmıştır.

\section{Veri Toplama Araçları}

$\mathrm{Bu}$ çalışmada araştırma verilerini elde etmek amacıyla 3 farklı veri toplama aracı kullanılmıştır:

\section{Başarı Testi}

Çalışmada, öğrencilerin akademik başarı düzeylerini ölçmek için "Bir Kahraman Doğuyor" ve "Milli Uyanış: Bağımsızlık Yolunda Atılan Adımlar" üniteleri ile ilgili 20 sorudan oluşan bir başarı testi uygulanmıştır. Üniteler, Atatürk 4D kartlarında yer alan kazanımlar doğrultusunda seçilmiştir. Testin hazırlanmasında ders kitabından ve geçmiş yıllarda çıkmış olan TEOG (Temel Eğitimden Ortaöğretime Geçiş) ve LGS (Lise Geçiş Sınavı) sınavı sorularından yararlanılmıştır. Hazırlanan başarı testi için, uygulama yapılacak okulda görev yapan 2 sosyal bilgiler öğretmeni ve 1 alan uzmanından görüş alınmıştır. Yapılan değerlendirme sonucunda geliştirilen başarı testi deney ve kontrol grupları için uygulanmıştır.

Tablo 1. Başarı Testinin Güvenilirliğine İlişkin Veriler

\begin{tabular}{ccccc}
\hline $\mathrm{n}$ & Soru Sayısı & $X$ & Ss & Güvenilirlik \\
\hline 59 & 20 & 78,47 & 9,72 &, 84 \\
\hline
\end{tabular}

\section{Artırılmış Gerçeklik Uygulamaları Tutum Ölçeği}

Deney grubu öğrencilerinin çalışmada artırılmış gerçeklik uygulamasına karşı tutumlarını ölçmek için Küçük, Yılmaz, Baydaş ve Göktaş (2014) tarafından geliştirilen Artırılmış Gerçeklik Tutum Ölçeği uygulanmıştır. Yapılan bu çalışma, araştırmacılar tarafından geliştirilen ölçme aracının boyutları ile ölçülmüştür. Ölçek, kullanma memnuniyeti 7, kullanma kaygısı 6, kullanma isteği 2 olmak üzere rastgele sıralanmış 15 maddeden oluşmaktadır. Her bir madde 5'li Likert tarzında düzenlenmiştir ve her madde için 5 “kesinlikle katılıyorum" ve 1 “kesinlikle katılmıyorum” aralığında değerlendirilmiştir.

Ölçeğin güvenirliği iç tutarlılık katsayısı Cronbach Alpha ile hesaplanmıştır. Küçük ve diğerlerinin (2014) yapmış oldukları çalışmada Cronbach Alpha değeri ,83 iken; yapılan bu çalışmanın analizi sonucunda ölçeğin Cronbach Alpha değeri ,81 olarak bulunmuştur. Ölçeğin yüksek derecede güvenilir olduğu kabul edilmiştir. 
8. Sınıf T.C. İnkılap Tarihi ve Atatürkçülük Dersinde Artırılmış Gerçeklik Uygulamalarının Öğrencilerin Akademik Başarılarına Etkisi ve Öğrencilerin Artırılmış Gerçeklik Uygulamasına Karşı Tutumları

\section{Açık Uçlu Soru Formu}

Araştırma kapsamında deney grubuna uygulama sürecinin değerlendirilmesi ve öğrencilere artıılmış gerçeklik uygulamasının katkılarının neler olduğunun belirlenmesi noktasında 2 sorudan oluşan açık uçlu soru formu uygulanmıştır.

\section{Uygulama Süreci}

Çalışma 2019-2020 eğitim öğretim yılının birinci döneminde Tokat ilinin Merkez ilçede bulunan bir ortaokulda T.C. İnkılap Tarihi ve Atatürkçülük dersini alan 59 kişiden oluşan 8.sınıf öğrencileri ile yapılmıştır. Çalışma öncesinde başarı testi öntest olarak uygulanmış, deney ve kontrol grupları oluşturulmuştur. Deney grubunu 31, kontrol grubunu ise 28 öğrenci oluşturmaktadır. Çalışmanın ilk haftasında başarı testi öntest olarak uygulanmış, ikinci haftasında deney ve kontrol grubunda çalışma gerçekleştirilmiş ve üçüncü haftasında ise başarı testi sontest uygulanmıştır.

İlk olarak artırılmış gerçeklik teknolojisi, deney grubu öğrencilerine tanıtılmıştır. Ardından 31 kişiden oluşan deney grubu öğrencileri, iş birliğine dayalı öğrenme yöntemine göre kendi içerisinde 5 gruba ayrılmıştır ve her gruba artırılmış gerçeklik kartları dağıtılmıştır. Önceden getirilmesi istenen akıllı telefonlarına veya tabletlerine artırılmış gerçeklik uygulaması indirildikten sonra Artge Kids yayınları tarafından geliştirilen Atatürk 4D artırılmış gerçeklik kartları ile Atatürk'ün çocukluğu, eğitim hayatı, katıldığı savaşlar ve milli mücadeledeki başarıları gibi birçok konu animasyonlar, 3 boyutlu modellemeler ve sesli anlatımlar ile sunulmuştur. Kartlar her grupla paralel olarak işlenmiş ve seslerin birbirine karışmaması için kulaklık aracılığı ile dinlemeleri sağlanmıştır. Sunulan her kart sonrasında öğrenciler ile soru cevap yöntemi ile değerlendirmeler yapılarak konu aktarılmaya çalışılmıştır. Sorulara öğrencilerin grupça cevap vermeleri istenmiştir. Ayrıca uygulama sırasında telefonları ya da tabletleri kartları desteklemeyen öğrencilerin, arkadaşları ile birlikte dinlemeleri sağlanmıştır. Uygulama sonrasında öğrencilere artırılmış gerçeklik uygulamasına karşı tutumlarını ölçmek amacıyla artırılmış gerçeklik tutum ölçeği uygulanmış ve dersin işlenişinin nasıl geçtiği ve uygulamanın öğrencilere nasıl bir katkısı olduğunu saptamak amacıyla açık uçlu soru formu uygulanmıştır. 28 öğrenciden oluşan kontrol grubuna ise sunu hazırlanarak soru-cevap ve anlatım yöntemiyle aynı konu işlenmiştir. Her iki gruba da anlatımlar gerçekleştirildikten sonra akademik başarılarına nasıl bir etkisi olduğunu saptamak için başarı testi sontest uygulanmıştır.

\section{Verilerin Analizi}

Çalışmanın nicel boyutunda, artırılmış gerçeklik uygulamasının öğrencilerin akademik başarılarına etkilerini belirlemek amacıyla, araştırmacı tarafından geliştirilmiş olan başarı testi uygulama öncesinde ve sonrasında öğrencilere uygulanmıştır. Veriler SPSS 20.0 programından yararlanılmıştır. Uygulamanın etkisini incelemek amacıyla iki grubun öntest ve sontest puanları Mann-Whitney $U$, aynı grubun öntest ve sontest puanları ise Wilcoxon testi ile karşılaştırılmıştır.

Çalışmanın nitel boyutunda ise açık uçlu soru formundan elde edilen veriler içerik analizi 
yöntemi ile analiz edilmiştir. İçerik analizi, birbirine benzeyen verilerin kavramlar ve temalar çerçevesinde bir araya getirilmesi ve anlaşılır bir biçimde düzenlenerek yorumlanmasıdır (Yıldırım ve Şimşek, 2018). Bu çalışmanın nitel boyutunda da katılımcılardan elde edilen veriler belirli temalar etrafında ele alınmış, fakat araştırmanın doğası gereği bu temaların sayısı fazla olmadığı için ayrıca tablolaştırmaya gidilmemiştir.

\section{Bulgular}

\section{Artırılmış Gerçeklik Uygulamasının Öğrencilerin Akademik Başarılarına Etkisine İlişkin Bulgular}

Uygulama öncesinde başarı testi deney ve kontrol gruplarına öntest olarak uygulanmış ve grupların konuya ilişkin akademik başarılarının birbirine yakın olup olmadığı incelenmiştir. Öntest sonuçları Mann-Whitney U testi ile analiz edilmiş, elde edilen sonuçlar Tablo 2'de gösterilmiştir.

Tablo 2. Deney ve Kontrol Gruplarının Öntest Sonuçları.

\begin{tabular}{llllll}
\hline Gruplar & $\mathrm{n}$ & $\bar{X}$ & Sira Ortalaması & $\mathrm{U}$ & $\mathrm{p}$ \\
\hline Deney Grubu & 31 & 80.06 & 33.47 & 326.50 & .102 \\
Kontrol Grubu & 28 & 76.71 & 26.16 & & \\
\hline
\end{tabular}

${ }^{*} \mathrm{p}>0.05$

Tablo 2' de görüldüğü üzere deney grubu öğrencilerinin öntest puan ortalaması 80.06 kontrol grubu öğrencilerinin ise 76.71 olarak bulunmuştur. Yapılan analiz sonucunda bu farkın anlamlı olmadığı ( $\mathrm{p}>0.05)$ sonucuna ulaşılmıştır. Böylelikle deney ve kontrol grubunun akademik başarılarının, uygulanan başarı testi itibariyle birbirine denk olduğu görülmüştür.

Uygulama gerçekleştirildikten sonra başarı testi deney grubuna sontest olarak uygulanmıştır. Elde edilen veriler Wilcoxon testi ile incelenmiş ve sonuçlar Tablo 3'te gösterilmiştir.

Tablo 3. Deney Grubu Öntest-Sontest Puan Ortalamalarının Karşılaştırılması

\begin{tabular}{lcccccc}
\hline Deney Grubu & $\mathrm{n}$ & $\bar{X}$ & $\begin{array}{l}\text { Sira } \\
\text { Ortalaması }\end{array}$ & $\begin{array}{l}\text { Sira } \\
\text { Toplamı }\end{array}$ & $\mathrm{z}$ & $\mathrm{p}$ \\
\hline Öntest & 31 & 80.06 & & & 4.68 & .000 \\
Sontest & 31 & 88.48 & & .00 & & \\
Negatif Sira & & & .00 & & & \\
Pozitif Sira & & & 14.50 & 406.00 & &
\end{tabular}

${ }^{*} \mathrm{p}<0.05$

Tablo 3'te görüldüğü üzere deney grubu öntest-sontest sonuçları arasında anlamlı farklılık olup son test puan ortalaması $(=88.48)$ öntest puan ortalamasından $(=80.06)$ daha yüksektir. $\mathrm{Bu}$ sonuç, artırılmış gerçekliğin deney grubu öğrencilerinin akademik başarıları üzerinde olumlu etki yarattığını göstermesi bakımından önemlidir.

Öğretim programının öngördüğü öğretim yaklaşımıyla uygulama gerçekleştirilen kontrol 
8. Sınıf T.C. İnkılap Tarihi ve Atatürkçülük Dersinde Artırılmış Gerçeklik Uygulamalarının Öğrencilerin Akademik Başarılarına Etkisi ve Öğrencilerin Artırılmış Gerçeklik Uygulamasına Karşı Tutumları

grubunda da başarı testi sontest olarak uygulanmıştır. Elde edilen veriler Wilcoxon testi ile incelenmiş ve sonuçlar Tablo $4^{\prime}$ te gösterilmiştir.

Tablo 4. Kontrol Grubu Öntest-Sontest Puan Ortalamalarının Karşılaştırılması

\begin{tabular}{lllllll}
\hline Kontrol Grubu & $\mathrm{n}$ & $\bar{X}$ & $\begin{array}{l}\text { Sira } \\
\text { Ortalamas1 }\end{array}$ & $\begin{array}{l}\text { Sira } \\
\text { Toplam1 }\end{array}$ & $\mathrm{z}$ & $\mathrm{p}$ \\
\hline Öntest & 28 & 76.71 & & 27 & 4.30 & .000 \\
Sontest & 28 & 84.89 & & .00 & & \\
Negatif Sıra & & & .00 & & & \\
Pozitif Sira & & & 12.50 & 300.00 & & \\
\hline
\end{tabular}

${ }^{*} \mathrm{p}<0.05$

Tablo 4'te görüldüğü üzere kontrol grubu öntest-sontest sonuçları arasında anlamlı farklılık olup son test puanları ( = 84.89) öntest puanlarından $(=76.71)$ daha yüksektir. Dolayısıyla programın öngördüğü öğretim anlayışının da katılımcıların akademik başarıları üzerinde olumlu bir etki yarattı̆̆ söylenebilir.

Deney ve kontrol gruplarının sontest puanlarının karşılaştırılması amacıyla Mann-Whitney U testi kullanılmış ve elde edilen sonuçlar Tablo 5'te gösterilmiştir.

Tablo 5. Deney ve Kontrol Gruplarının Sontest Puan Ortalamalarının Karşılaştırılması

\begin{tabular}{llllll}
\hline Gruplar & $\mathrm{n}$ & $\bar{X}$ & Sira Ortalaması & $\mathrm{U}$ & $\mathrm{p}$ \\
\hline Deney Grubu & 31 & 88.48 & 34.11 & 2.014 & .047 \\
Kontrol Grubu & 28 & 84.89 & 24.45 & & \\
\hline
\end{tabular}

"p $<0.05$

Tablo 5'te görüldüğü üzere deney grubu öğrencilerinin sontest puan ortalaması 88.48; kontrol grubu öğrencilerinin sontest puan ortalamaları ise 84.49 olarak bulunmuştur. Yapılan analiz sonucunda bu farkın anlamlı olduğu $(\mathrm{p}<0.05)$ sonucuna ulaşılmıştır. Buna göre deney grubu öğrencilerinin kontrol grubu öğrencilerine göre daha başarılı olduğu söylenebilir.

\section{Artırılmış Gerçeklik Uygulamasına Yönelik Öğrencilerin Tutumlarına İlişkin Bulgular}

Deney grubunun artırılmış gerçeklik uygulamasına yönelik tutumlarının puan ortalamaları Tablo 6' da gösterilmektedir.

Tablo 6. Artırılmış Gerçeklik Uygulaması Tutum Ölçeği Puan Ortalamalarının Sonuçları

\begin{tabular}{llllll}
\hline & $\mathrm{n}$ & Min. & Max. & $\bar{X}$ & ss \\
\hline Deney Grubu & 31 & 3.07 & 5,00 & 4.16 & .509
\end{tabular}

Tablo 6'da deney grubu öğrencilerin artırılmış gerçeklik uygulamasına yönelik tutumlarının ortalamalarına ilişkin istatistik analiz sonuçları verilmiştir. Deney grubu öğrencilerinin ortalamaları 4.16 olarak bulunmuştur. Ölçeğin beşli likert tipinde geliştirildiği düşünüldüğünde artırılmış gerçeklik uygulamışını deneyimleyen katılımcıların, bu 
uygulamaya yönelik olumlu bir tutum içinde bulunduğu söylenebilir.

\section{Artırılmış Gerçeklik Uygulaması İle İşlenen Dersin Sürecine İlişkin Bulgular}

Öğrencilerin "Bu dersin nasıl geçtiğini düşünüyorsunuz? Nedenleri ile birlikte açıklayınız." sorusuna dair görüşlerine baktığımızda, çoğu öğrencinin ifadelerinin güzel ve eğlenceli temaları etrafında ifadelerinin toplandığını görmekteyiz. Öğrencilerin bu doğrultuda görüşleri ise şu şekildedir: "Güzel ve eğlenceliydi" (Ö2) "Arkadaşlarım ile vakit geçirerek konuyu işledim" (Ö7) ve "3 boyutlu olması hoşuma gitti. Uygulamayla öğrenmek daha zevkli" (Ö3). "Çünkü bu sayede hafizamda daha kolay yer edinebiliyorlar. Hatta "İnkllap dersini çok sevmediğim halde seomeye başladım" (Ö8) demiştir. Diğer bir katılımcı ise "Illk defa böyle bir şey denedim" (Ö11). "3D görselli ve sesli anlatımlar dersleri daha zevkli hale getirir" (Ö19) ifadelerini kullanmışlardır.

Öğrencilerin bazıları ise işlenen dersle ilgili verimlilik, öğreticilik ve kullanılabilirlik temalarına vurgu yapmışladır. Öğrencilerin bu doğrultuda görüşleri ise şu şekildedir: “Bu dersin verimli ve çok eğlenceli geçtiğini düşünüyorum. Çünkü, anlatım yapılırken uygulamada görüntüyü hareket ettiriyoruz ve daha ayrintıl anliyoruz" (Ö12) "3 boyutlu animasyonlar hem eğlendirdi hem öğretti" (Ö13) "Çünkü daha fazla bilgilendiriciydi" (Ö14) "Bence tüm dersler böyle geçse çok güzel olur" (Ö21) ifadelerini kullanmışlardır.

Artırılmış gerçeklik uygulaması ile işlenen dersin yarattığı gerçeklik hissi, öğrencilerin ön plana çıkardığı temalarından birisidir. Bu doğrultuda öğrenciler "...olayları yaşarcasına oluyorum" (Ö16) ve “..uygulama gerçeklik hissi veriyor, güzeldi" (Ö31) ifadelerini kullanmışlardır.

Öğrencilerin bazılarının vurguladığı teknolojik sınırlılıklar bu soruda olumsuz bir tema olarak karşımıza çıkmaktadır. Öğrencilerin bu doğrultuda görüşleri şu şekildedir: “... uygulama bazı telefonları desteklemedi" (Ö28) buna istinaden "Benim kullandiğım telefon çoğu kartı desteklemedi" (Ö31) bu yüzden “...birazda olsa zaman kaybı oldu” (Ö26) ifadelerini kullanmışlardır.

\section{Artırılmış Gerçeklik Uygulamasının Katılımcılara Katkılarının Neler Olduğuna İlişkin Bulgular}

Öğrencilerin “Artırılmış gerçeklik uygulamasının size katkılarının neler olduğunu düşünüyorsunuz? Açıklayınız." sorusuna dair görüşlerine baktığımızda, çoğu öğrencinin ifadesinin derse karşı ilgi, merak ve dersi anlama teması etrafında birleştiğini görmekteyiz. Öğrencilerin bu doğrultuda görüşleri şu şekildedir: "Derse ilgim daha çok arttı" (Ö5) Dersin işlenişi "3 boyutlu olduğu için konuya olan merakım arttı" (Ö21) bu sayede "Konuları daha iyi anladığımı düşünüyorum" (Ö11) Çünkü "Akılda kalıcı görseller vardı ve iyi anlatılıyordu" (Ö26) ifadelerini kullanmışlardır.

Artırılmış gerçeklikle işlenen dersin öğrencilere bir diğer katkılarına baktı̆̆ımızda uygulamanın öğrencilerin görüşleri doğrultusunda öğrenmeyi kolaylaştırma, akılda kalıcılık ve gerçekçi bakış açısı teması etrafında görüşlerini vurguladıklarını görmekteyiz. Bu doğrultuda öğrencilerin ifadeleri şu şekildedir: Konunun "Görseller sayesinde daha akılda kalıcı olduğunun düşünüyorum" (Ö15) ve bu da "Öğrenmemi kolaylaştırıyor" (Ö30) Aynı zamanda "Geçmişte geçirdiğgimiz zor günleri gerçekçi bir bakış açısıyla öğrendiğimi düşünüyorum" (Ö16) ifadelerini kullanmışlardır. 
8. Sınıf T.C. İnkılap Tarihi ve Atatürkçülük Dersinde Artırılmış Gerçeklik Uygulamalarının Öğrencilerin Akademik Başarılarına Etkisi ve Öğrencilerin Artırılmış Gerçeklik Uygulamasına Karşı Tutumları

Artırılmış gerçeklik uygulamasının çok katkısı olmadığını düşünen Ö31 ise "Pek bir katkısı olduğunu düşünmüyorum. Sadece arkadan anlatan sesin yararı olacağına inanıyorum" ifadesini kullanmıştır.

\section{Tartışma}

$\mathrm{Bu}$ çalışmada öğrencilerin, 8.sınıf T.C. İnkılap Tarihi ve Atatürkçülük dersinde artırılmış gerçeklik uygulaması ile konuların öğretiminde akademik başarılarına etkisi ve artırılmış gerçeklik uygulamasına karşı öğrencilerin tutumları incelemiştir.

Araştırma kapsamında ortaya koyulan alt problemlerden birincisi artırılmış gerçeklik uygulamasının, öğrencilerin akademik başarıları üzerindeki etkisi olmuştur. Öğrencilerin başarılarını değerlendirmek amacıyla başarı testi hazırlanmış ve sonuçlar Mann-Whitney U testi ile incelenmiştir. Elde edilen sonuçlara göre, artırılmış gerçeklik uygulaması ile ders yapan deney grubu öğrencileri; programın öngördüğü şekilde ders yapan kontrol grubu öğrencilerine göre daha başarılı olmuştur. Benzer şekilde Abdüsselam ve Karal'ın (2012) fizik dersinde, Ersoy, Duman ve Öncü'nün (2016) ise görsel tasarım ilkeleri konusunda artırılmış gerçekliğin uygulandığı deney grubu öğrencileri, kontrol grubu öğrencilerine göre daha başarılı olmuştur. Sonuç olarak diğer disiplinlerde de yapılan çalışmaların sonuçlarına baktığımızda artırılmış gerçeklik uygulaması ile işlenen dersler, geleneksel yöntemle işlenen derslere göre öğrencilerin akademik başarı düzeyini artırmada daha başarılıdır.

Araştırma kapsamında ortaya koyulan ikinci alt problem noktasında deney grubu öğrencilerinin artırılmış gerçeklik uygulamasına karşı tutumları, Artırılmış Gerçeklik Uygulamaları Tutum Ölçeği ile incelenmiştir. Araştırmanın istatistik analizi sonucunda öğrencilerin artırılmış gerçeklik uygulamasına karşı olumlu bir tutum oluşturduğu sonucuna ulaşılmıştır. Bu sonuca göre, artırılmış gerçeklik uygulamalarının öğrenme sürecinde olumlu yönde etkiler oluşturmasında, öğrencilerin bu tür artırılmış gerçeklik uygulamalarına yönelik tutumları önemli bir faktör olarak ortaya çıkmaktadır (Küçük vd., 2014).

Artırılmış gerçeklik uygulaması ile işlenen dersin sürecine ilişkin bulgular kısmına baktığımızda öğrencilerin çoğu, artırılmış gerçeklik uygulaması ile işlenen derslerin daha güzel; arkadaşları ile iş birliği içinde oldukları için dersin daha eğlenceli; uygulamanın 3 boyutlu olmasından dolayı birçok duyuya hitap ettiği için konuların hafızalarında daha kolay yer edindiği ve hatta İnkılap Tarihi ve Atatürkçülük dersini sevmedikleri halde uygulama sayesinde sevmeye başladıklarını dile getirmişlerdir. Benzer şekilde Çetinkaya ve Akçay'ın (2013) yapmış oldukları eğitim ortamlarında artırılmış gerçeklik uygulamalarına dikkat çektikleri çalışmalarında "öğrencilerin etkileşim ve iş birliği içinde olduğu, yaparak öğrendiği, ilgi çekici ve farklı duyulara hitap eden artırılmış gerçeklik uygulamaları istendik davranışların kazandırılma sürecinde ayrı bir öneme sahiptir" sonucuna ulaşmışlardır. Aynı zamanda çoğu öğrencinin görüşlerine göre artırılmış gerçeklikle işlenen derslerin verimli geçtiği, anlatım yapılırken kontrolün ellerinde olduğu için yaparak yaşayarak öğrenmeyi sağladığından konuyu daha ayrıntılı olarak anlamaktadır. Bununla birlikte 3 boyutlu animasyonlar ile konunun eğlendirici ve öğretici nitelikte olduğu, konunun daha fazla bilgilendirici yönde olduğu ve diğer derslerde de kullanılması gerektiği sonucuna da 
ulaşılmıştır. Durak ve Karaoğlan Yılmaz'ın (2019) artırılmış gerçeklik uygulamalarına yönelik öğrencilerin görüşlerinin değerlendirilmesi üzerine yapmış oldukları çalışma ile de eğlenceli öğrenme ortamı sunması ve artırılmış gerçeklik uygulamalarının diğer derslerde de kullanılması noktasında benzer sonuçlar elde edilmiştir.

Ders sürecinde ayrıca öğrenciler telefonlarının uygulamayı desteklemediğini ve bu yüzden zaman kaybına uğradıklarını belirtmişlerdir. Bu durum ile, uygulama ile kullanılan teknolojilerin entegrasyonunun yetersiz olması sonucuna ulaşılmaktadır. Alan yazına baktığımızda Koçoğlu, Akkuş ve Özhan'ın (2016) sosyal bilgiler eğitiminde kullanımı üzerine yapmış oldukları çalışmalarında artırılmış gerçeklik uygulaması ile ilgili teknolojik sınırlılıklar, cihazlarda yaşanan teknik sıkıntılar gibi dezavantajlarından bahsedilmiştir. Ayrıca Taşkıran, Koral ve Bozkurt'un (2015) artırılmış gerçeklik uygulamasının yabancı dil öğretimi üzerine yapmış oldukları çalışmada da teknik nedenlerden kaynaklanan dezavantajlar ile karşılaşılmıştır. Bu gibi aksaklıkların meydana gelmemesi için teknik kısımların tekrar gözden geçirilmesi gerektiği önerilmektedir.

Artırılmış gerçeklik uygulamasının katılımcılara katkılarının neler olduğuna ilişkin sonuçlara baktığımızda öğrencilerin çoğu, uygulama sayesinde derse ve konuya karşı ilgi ve meraklarının arttığını, akılda kalıcı görseller sayesinde konuları daha iyi anladıklarını, uygulamanın öğrenmeyi kolaylaştığını ve olaylara karşı farklı bakış açısı kazandıklarını ifade etmişlerdir. Öğrencilerin görüşleri doğrultusunda artırılmış gerçeklik uygulamalarının kullanılması ile öğrenmeyi içselleştirdikleri, görseller sayesinde konunun somutlaştırıldığ için akılda kalıcılığı sağladığ gibi etkenlerden ötürü derse karşı olan tutumlarının olumlu yönde olduğu sonucuna ulaşılmaktadır. Durak ve Karaoğlan Yılmaz'ın (2019) yapmış oldukları çalışma ile de artırılmış gerçeklik uygulamalarının öğrencilerin görüşleri doğrultusunda öğrencilere katkılarının, "nesne veya durumların artırılmış gerçeklik uygulamalarıyla canlandırılması konuları görselleştirerek, ilgi çekici hale getirmekte" olduğu sonucuna ulaşmışlardır. Aynı zamanda bulgular sonucunda artırılmış gerçeklik uygulamasının derste kullanılmasının çok katkısı olmadığını düşünen öğrenci de bulunmaktadır.

Sonuç olarak artırılmış gerçeklik uygulaması ile işlenen derslerin, geleneksel yöntemle işlenen derse göre öğrencilerin daha başarılı oldukları ve deney grubu öğrencilerinin artırılmış gerçeklik uygulamasına karşı olumlu bir tutuma sahip oldukları sonucuna ulaşılmıştır. Yaşadığımız yüzyıl itibari ile bilim ve teknolojide yaşanan değişimler, öğrencilerin geleneksel derslerden ziyade teknoloji destekli uygulamalar ile işlenen derslerden daha çok verim aldıkları, derslere daha fazla ilgi ve istekle girdikleri, derse karşı hazırbulunuşluk düzeylerinin arttığı görülmektedir. Özellikle soyut bir içeriğe sahip olan sosyal bilgiler ve T.C. İnkılap Tarihi ve Atatürkçülük dersi kapsamında öğrencilerin soyut kavramları tam olarak kavrayamadıklarından, 3 boyutlu görseller ve animasyonlar sayesinde içeriğin somutlaştırılması, teknoloji destekli uygulamaların derslerde kullanılması gerekliliğini ortaya koymaktadır. Fakat her öğretim teknolojisinde olduğu gibi artırılmış gerçeklik uygulamalarında da ulaşılabilirlik ve teknolojinin öğrenme ortamına entegrasyonu konusunda sınırlılıkların bulunduğu da öğretmenler tarafından dikkate alınmalıdır. 
8. Sınıf T.C. İnkılap Tarihi ve Atatürkçülük Dersinde Artırılmış Gerçeklik Uygulamalarının Öğrencilerin Akademik Başarılarına Etkisi ve Öğrencilerin Artırılmış Gerçeklik Uygulamasına Karşı Tutumları

\section{Kaynakça}

Abdüsselam, M.S. ve Karal, H. (2012). Fizik öğretiminde artırılmış gerçeklik ortamlarının öğrenci akademik başarısına etkisi: 11. Sınıf manyetizma konusu örneği. Eğitim ve Öğretim Araştırmaları Dergisi, 1(4), 170-181.

Aoyama, R. ve Tse, H. (2017, Nisan). Using augmented reality and gamification to make history field trips more engaging for university students. 6th International Conference on Language, Education, Humanities and Innovation'da sunuldu, Singapur.

Aycan, Y. (2010). İlköğretim 8.sını öğrencilerinin Türkiye Cumhuriyeti inkılap Tarihi ve Atatürkçülük dersinde yer alan kavramları anlama düzeyleri ve kavram yanılgıları (Gördes örneği). Yayımlanmamış yüksek lisans tezi, Celal Bayar Üniversitesi Sosyal Bilimler Enstitüsü, Manisa.

Aydın, B. (2003). Bilgi toplumu oluşumunda bireylerin yetiştirilmesi ve matematik öğretimi. Pamukkale Üniversitesi Eğitim Fakültesi Dergisi, 2(14), 183-190.

Azuma, R.T. (1997). Survey of augmented reality. Presence: Teleoperators \& Virtual Environments, 6(4), 355-385.

Billinghurst, M. ve Duenser, A. (2012). Augmented reality in the classroom. Computer, 45(7), 56-63. DOI: 10.1109/MC.2012.111

Braun, J.A. (1999). Ten ways to integrate technology into middle school social studies. The Clearing House, 72(6), 345-351.

Büyüköztürk, Ş., Çakmak, K.E., Akgün, Ö.E., Karadeniz, Ş. ve Demirel, F. (2018). Eğitimde bilimsel araştırma yöntemleri. Ankara: Pegem Akademi.

Challenor, J. ve Ma, M. (2019). A review of augmented reality applications for history education and heritage visualisation. Multimodal Technologies and Interaction, 3(2), 39. DOI: $10.3390 / \mathrm{mti} 3020039$

Chang, Y. L., Hou, H. T., Pan, C. Y., Sung, Y. T. ve Chang, K. E. (2015). Apply an augmented reality in a mobile guidance to increase sense of place for heritage places. Journal of Educational Technology \& Society, 18(2), 166-178. DOI: 10.1080/10494820.2019.1636073

Çetinkaya, H.H. ve Akçay, M. (2013, Ocak). Eğitim ortamlarında artırılmış gerçeklik uygulamaları. XV. Akademik Bilişim Konferansı'nda sunuldu, Antalya.

Di Serio, A., Ibanez, M.B. ve Kloos, C.D. (2013). Impact of on augmented reality system on students' motivation for a visual art course. Computers and Education, 68, 586-596. DOI: 10.1016/j.compedu.2012.03.002

Durak, A. ve Karaoğlan Yılmaz, F.G. (2019). Artırılmış gerçekliğin eğitsel uygulamaları üzerine ortaokul öğrencilerinin görüşleri. Bolu Abant İzzet Baysal Üniversitesi Ĕ̆gitim Fakültesi Dergisi, 19(2), 468-481.

Erbaş, Ç. ve Demirer, V. (2014). Eğitimde artırılmış gerçeklik uygulamaları: Google glass örneği. Journal of Instructional Technologies and Teacher Education, 3(2), 8-16.

Ersoy, H., Duman, E. ve Öncü, S. (2016). Artırılmış gerçeklik ile motivasyon ve başarı: deneysel bir çalışma. Journal of Instructional Technologies \& Teacher Education, 5(1), 39-44. 
Gümbür, Y. (2019). Sosyal bilgiler dersinde artırılmış gerçeklik uygulaması kullanımının öğrencilerin akademik başarısına, tutumuna ve motivasyonuna etkisi. Yayımlanmamış yüksek lisans tezi, Muğla Sıtkı Koçman Üniversitesi Eğitim Bilimleri Enstitüsü, Muğla.

Heafner, T. (2004). Using technology to motivate students to learn social studies. Contemporary Issues in Technology and Teacher Education, 4(1), 42-53.

Jenkins, H., Purushotma, R., Weigel, M., Clinton, K. ve Robison, A. J. (2009). Confronting the challenges of participatory culture: Media education for the 21st century. Cambridge: MIT Press.

Koçoğlu, E., Akkuş, İ. ve Özhan, U. (2016). Yeni bir öğrenme ortamı olarak artırılmış gerçeklik uygulamalarıyla sosyal bilgiler öğretimi. R. Sever, M. Aydın ve E. Koçoğlu (Editör). Alternatif yaklaşımlarla sosyal bilgiler eğitimi içinde (s. 327-354). Ankara: Pegem Akademi.

Küçük, S., Yımaz, R.M., Baydaş, Ö. ve Göktaş, Y. (2014). Ortaokullarda artırılmış gerçeklik uygulamaları tutum ölçeği: geçerlik ve güvenirlik çalışması. Eğitim ve Bilim Dergisi, 39(176), 383-392.

MEB (2018). Sosyal bilgiler dersi öğretim programı. Ankara: Milli Eğitim Yayınları.

MEB (2018). T.C. İnkılap Tarihi ve Atatürkçülük dersi öğretim programı. Ankara: Milli Eğitim Yayınları.

Özarslan, Y. (2011, Eylül). Öğrenen içerik etkileşiminin genişletilmiş gerçeklik ile zenginleştirmesi. V. International Computer and Instructional Technologies Symposium (IEITS 2011)'da sunuldu, Elazı̆̆

Rice, M.L. ve Wilson, E.K. (1999). How technology aids constructivism in the social studies classroom. The Social Studies, 90(1), 28-33.

Santos, M. E., Chen, A., Taketomi, T., Yamamoto, G., Miyazaki, J. ve Kato, H. (2013). Augmented reality learning experiences: Survey of prototype design and evaluation. IEEE Transactions on Learning Technologies, 7(1), 38-56. DOI: 10.1109/TLT.2013.37

Schiavi, B., Gechter, F., Gechter, C. ve Rizzo, A. (2018, Mart). Teach me a story: an augmented reality application for teaching history in middle school. IEEE Conference on Virtual Reality and 3D User Interfaces (VR)'da sunuldu, Germany.

Tangülü, Z., Tosun, A. ve Kocabıyık, B. (2014). Ortaokul 8.sınıf inkılap tarihi ve Atatürkçülük konularının öğretiminde karşılaşılan sorunların sosyal bilgiler öğretmen görüşlerine göre değerlendirilmesi. Trakya Üniversitesi Sosyal Bilimler Dergisi, 16(2), 233-245.

Taşkıran, A., Koral, E. ve Bozkurt, A. (2015, Şubat). Artırılmış gerçeklik uygulamasının yabancı dil öğretiminde kullanılması. XVII Akademik Bilişim Konferansı'nda sunuldu, Eskişehir.

Wojciechowski, R. ve Cellary, W. (2013). Evaluation of learners' attitude toward learning in aries augmented reality environments. Computers and education, 68, 570- 585.

Wu, H. K., Lee, S. W., Chang, H. Y. ve Liang, J. C. (2013). Current status, opportunities and challenges of augmented reality in education. Computers $\mathcal{E}$ Education, 62, 41-49. DOI: 10.1016/j.compedu.2012.10.024

Yıldırım, A. ve Şimşek, H. (2018). Sosyal bilimlerde nitel araştırma yöntemleri. Ankara: Seçkin Akademik ve Mesleki Yayınlar. 
8. Sınıf T.C. İnkılap Tarihi ve Atatürkçülük Dersinde Artırılmış Gerçeklik Uygulamalarının Öğrencilerin Akademik Başarılarına Etkisi ve Öğrencilerin Artırılmış Gerçeklik Uygulamasına Karşı Tutumları

Zhao, Y. (2007). Social studies teachers' perspectives of technology integration. Journal of technology and teacher education, 15(3), 311-333. 